
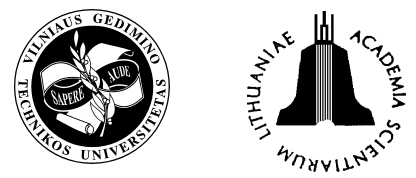

\title{
MODERN ACCOUNTING METHOD IN INSURANCE TARIFFS - NOVELTY ON THE INSURANCE MARKET
}

\author{
Stasys Girdzijauskas ${ }^{1}$, Jonas Čepinskis ${ }^{2}$, Edita Jurkonytė ${ }^{3 *}$ \\ ${ }^{1}$ Dept of Informatics, Kaunas Faculty of Humanities, Vilnius University, Muitinès g. 8, LT-44280 Kaunas, \\ Lithuania.E-mail: stasys.girdzijauskas@vukhf.lt \\ ${ }^{2}$ Dept of Finance, Faculty of Economics and Management, Vytautas Magnus University, Daukanto g. 28, \\ LT-44246Kaunas,_Lithuania.E-mail:Jonas_Cepinskis@fc.vdu.lt \\ ${ }^{3}$ Kaunas City Municipality, Specialist of Controller's Office, Laisvès al. 94 , LT-44251 Kaunas, Lithuania. \\ E-mail: edita.jurkonyte@kaunas.lt
}

Received 24 Febr 2007; accepted 25 July 2007

\begin{abstract}
The insurance calculation could be based on the logistic limit model of the population evolution. The investigation has shown that a newly invented logistic theory could be applied to the calculation of interest or the estimation of investment projects, as well as to discount of value expressions, determination of the present monetary values, and management of money currents, that means it could be adapted to calculation of insurance annuities either. There are concrete examples in the article which state that a new principle calculation system is possible based on the logistic discount. Although calculations are more complicated and completely possible only using information technologies, yet the results achieved on the basis of the logistic theory are more accurate and more reliable. To say more, the application of the logistic theory offers qualitatively new results. The main target of this article is to present modern method of calculating annuity insurance tariffs and to compare usual and logistic methods of calculating annuities insurance tariffs. The tasks of the article are: a) to discuss about insurance on living to a certain age peculiarity and b) to analyse and to compare usual and logistic annuities insurance tariffs accounting.
\end{abstract}

Keywords: insurance market, insurance tariffs, usual and logistic annuities, logistic capital, capital resources.

\section{Introduction}

Success of the activity is determined by the ability to rationally dispose certain resources. Limitation of resources by its nature being one of the most important factors of system development usually is not enough appreciated. It is influenced not only by complicated measurement of the majority of resources, but also it appears because of the lack of easy and reliable analysis measures. Usually it is not possible to anticipate the influence of the resources and future results. All this is conditioned by a situation that resources generally are not appreciated.

Currently various long-term investment instruments are becoming more and more popular, it is sought for measures that would be able to increase the old age income, which are alternative to the state social insurance. Due to that higher requirements are put for the service providers, for whom the guarantee of successful activity is the equivalence of contributions from every investor and member of the transaction and pay offs.

* Corresponding author
The main target of this article is to present modern method of calculating annuity insurance tariffs and to compare usual and logistic methods of calculating annuities of these tariffs.

The article tasks are:

1. To discuss the insurance on living to a certain age peculiarity;

2. To analyse and to compare usual and logistic annuities insurance tariffs accounting.

Switchboard functions are used for calculating the standard insurance annuity tariffs, which facilitate markings and allow shorter expression of complicated aspect sequences, clearer and more imaginative provision of their schemes $[1,2]$.

When performing the logistic calculations of insurance annuities, the ambiguity of the results is faced (phenomenon of hysteresis): having calculated the future value of a certain meaning and then the current value of the received meaning, the results do not coincide. This ambiguity is a little bit more revealed only when the resource norms are rather low (as indicated by Cameron [3]). 


\section{Insurance on living to a certain age}

For the calculation of insurance tariffs the possibilities to live to a certain age or do not survive to the respectful age are used.

If $n$ - the number of years that are planned to be live, then the possibility to live from $x$ until $x+n$ years is marked ${ }_{n} p_{x}$ [4]. The possibility is:

$$
{ }_{n} p_{x}=\frac{l_{x+n}}{l_{x}}
$$

here $l_{x}$ and $l_{x+n}$ - respectively the number of persons who are from $x$ to $x+n$ years old.

The possibility to die before a certain age can be calculated as a possibility to survive to a certain age:

$$
q_{x}=1-p_{x}=1-\frac{l_{x+1}}{l_{x}}=\frac{l_{x}-l_{x+1}}{l_{x}}=\frac{d_{x}}{l_{x}},
$$

here $q_{x}$ - the possibility, to become $x$ years old, to die the next year after $(x+n)$.

Analysing the case of life insurance, when the insured receives the sum envisaged in the insurance contract only after living to a certain age, we reason in the following way: all persons, who become $x$ years old, at the same period conclude the contract that if they live $n$ years more, they will receive a payoff of $S$ Euro. Let's suppose that the insurance contract of $n$ years is concluded by all men who are $x$ years old. There is $l x$ number of such men. Not all the insured persons will live to the envisaged term. Thus the number will be equal to $l x+n$. $S$ Euro will have to be paid off to each of them, therefore the total sum of money will be $l x+n \cdot S$. Nevertheless, this sum will have to be paid off only in $n$ years. Therefore its current logistic value, at the interest norm of $p$ percent $(i=p / 100)$, marginal capital value (capital resources) $S_{m}$ and pay off $S$, is the following:

$$
\frac{l_{x+n} \cdot S \cdot S_{m}}{l_{x+n} \cdot S+\left(S_{m}-l_{x+n} \cdot S\right) \cdot(1+i)^{n}}
$$

For example, the insurance contract is concluded for 20 years $(n=20)$ by all 30 year old men $(x=30)$. The number of them, in accordance with the life expectancy tables ([5], is equal $97117\left(l_{30}=97117\right)$. From the same tables we find how many persons will live to 50 years $\left(l_{30+20}=\right.$ 82 887). Moreover, let's suppose that capital resources $S_{m}=10^{10}$ Euro, pay off $S=1$ Euro, and the interest norm $i=0,035$. In such a case the current value is:

$$
\frac{82887 \cdot 1 \cdot 10^{10}}{82887 \cdot 1+\left(10^{10}-82887 \cdot 1\right) \cdot 1,035^{10}}=58760 \text { Euro. }
$$

For collecting the calculated sum of 58760 Euro, now it is necessary to take from every insured customer $\frac{58760}{l_{50}}=\frac{58760}{82887} \approx 0,711785$ Euro. It means that a 40 years old insured will receive 1 Euro in 10 years, if now he paid almost 71 euro cents, and for receiving, for example, 1000 Euro he must pay 711,78 Euro. The latter sum will be received only if the marginal capital will be increased the same number of times (ie 1 000) as the pay off $S$.

Then, supposing that ${ }_{n} p_{x}=\frac{l_{x+n}}{l_{x}}$, it is possible to claim that the non-recurring net bonus $A_{x+n}$ in case of living to certain age (survival) insurance is the mathematical mean of the insurance sum $\mathrm{S}$ discounted for the term of the insurance:

$$
A_{x+n}=\frac{{ }_{n} p_{x} \cdot S \cdot S_{m}}{{ }_{n} p_{x} \cdot S+\left(S_{m}-{ }_{n} p_{x} \cdot S\right) \cdot(1+i)^{n}} .
$$

\section{Calculation and comparison of the standard and logistic annuity insurance tariffs}

The rents can be calculated based on the calculations of the standard or logistic annuity insurance tariffs.

First of all, let's analyse the rent paid out by prenumerando (the beginning of period) in accordance with the standard insurance annuities. For example, the insured now pays a certain sum of money, ie bonus $\alpha_{x}$ so that he would receive from the insurer at the beginning of every year for life 1 Euro. Let's establish the tariff payment of such rent or the current value of such rent (noted by Bland [6]).

Implementing such contract, the insured at the beginning of the first year must pay the insurer 1 Euro. If the insurer ill survive the first year, then at the beginning of the second year the insurer will pay off another 1 Euro etc.

Therefore the first contribution of 1 Euro must be paid immediately after signing the contract and the possibility that this contribution will be paid is equal 1 , ie

$$
p_{1}=\frac{l_{x}}{l_{x}}=1
$$

If he person was insured when he was $\mathrm{x}$ years old, the possibility that he will survive the first year after the insurance (will survive till the beginning of the second year), equals:

$$
p_{2}=\frac{l_{x+1}}{l_{x}} .
$$

From here we see that the average that the insured will receive 1 Euro at the beginning of the second year is:

$$
\frac{l_{x+1}}{l_{x}} \cdot 1 \text { Euro. }
$$

This sum will be paid off by the insurer, while the insured must pay his bonus now; therefore the received sum still has to be discounted. In such a case we receive the following:

$$
\frac{l_{x+1}}{l_{x}} \cdot 1 \cdot v
$$


here $v$ - discount coefficient coinciding with the interest norm $i$.

There is an analogous possibility that the insured, who is $x$ years old, will survive till the beginning of the third year (will survive the second year) is the following:

$$
p_{3}=\frac{l_{x+2}}{l_{x}} .
$$

Therefore the sum currently to be taken from the customer now is:

$$
\frac{l_{x+1}}{l_{x}} \cdot 1 \cdot v^{2}
$$

We continue such reasoning until $l_{x}$ column in the mortality table ends, ie until the marginal age of the customer $w$ is reached. Having summed up all the received sums, we will receive the calculated bonus $\alpha_{x}$, ie. the sum payable by the insured now, so that every year, until he is alive, he would receive 1 Euro of pension.

$$
a_{x}=1+\frac{l_{x}+1}{l_{x}} \cdot v+\frac{l_{x}+2}{l_{x}} \cdot v^{2}+\ldots+\frac{l_{w}}{l_{x}} \cdot v^{w-x}
$$

Having multiplied and divided every member of this equation from $v^{x}$, we will get:

$$
a_{x}=\frac{l_{x} \cdot v^{x}}{l_{x} \cdot v^{x}}+\frac{l_{x+1} \cdot v^{x+1}}{l_{x} \cdot v^{x}}+\frac{l_{x+2} \cdot v^{x+2}}{l_{x} \cdot v^{x}}+\ldots+\frac{l_{w} \cdot v^{w}}{l_{x} \cdot v^{x}} .
$$

The product $l_{x} \cdot v^{x}$ is relatively considered the re-calculated (discounted) number of the persons who are $x$ years old. This amount in the mortality tables is marked by the symbol $D_{x}$. Analogous product:

$$
l_{x+m} v^{x+m}=D_{x+m}
$$

Having inserted the marking, we will receive:

$$
a_{x}=\frac{D_{x}+D_{x+1}+D_{x+2}+\ldots+D_{w}}{D_{x}} .
$$

Since $D_{x}+D_{x+1}+D_{x+2}+\ldots+D_{w}=N_{x}$, then the non-recurring pension paid by the customer $\alpha_{x}$, calculated using switchboard functions in case of prenumerando is:

$$
a_{x}=\frac{N_{x}}{D_{x}} .
$$

Analogically reasoning it is possible to write down the amount of the non-recurring pension in case of the postnumerando (the end of period) paid rent:

$$
a_{x}^{\prime}=\frac{N_{x+1}}{D_{x}} .
$$

Let's analyse an example. Let's calculate, a non-recurring bonus must be paid by a 60 -year old man, who is willing to receive the annual rent of 2800 Euro paid by prenumerando until he is alive.

Based on the formula (2) and the tables, where $N_{60}=$
96628,35 and $D_{60}=8496,57$, we can write down:

$$
a_{60}=\frac{N_{60}}{D_{60}}=\frac{96628,35}{8496,57}=11,4089 \text { Euro. }
$$

Therefore, a sixty year old man, who is willing to receive the annual rent of 1 Euro paid by prenumerando until he is alive, must pay a net bonus of 114089 Euro. If every year not 1 Euro is paid, let's say a rent of 2800 Euro, then the non-recurring bonus will be bigger by 2800 Euro:

$$
11,4089 \cdot 2800=31944,92 \text { Euro. }
$$

The rent paid by prenumerando, analysed in accordance with the logistic insurance annuities, differs from the calculation of the standard insurance annuity non-recurring bonuses [7]. The bonus is marked by $A_{x}$. So, if the insured who is willing to, just like in case of standard insurance annuities, receive from the insurer at the beginning of every year a sum of $S$ Euro, it is necessary to pay a lump bonus $A_{x}$.

The possibility that he will survive in the first year after the insurance (he will live to the beginning of the second year), is equal to:

$$
{ }_{1} p_{x}=\frac{l_{x+1}}{l_{x}} .
$$

The mathematical expectancy that at the beginning of the second year the insured will receive a sum of $S$ Euro is equal:

$$
\frac{l_{x+1}}{l_{x}} \cdot S={ }_{1} p_{x} \cdot S \quad \text { Euro. }
$$

Since this sum will be paid in a year by the insurer, while the insured has to pay his bonus now, therefore, just like when calculating the standard insurance annuities, we will discount the received sum. In such a case we receive the following:

$$
S_{1}=\frac{{ }_{1} p_{x} \cdot S \cdot S_{m}}{{ }_{1} p_{x} \cdot S+\left(S_{m}-{ }_{1} p_{x} \cdot S\right) \cdot r},
$$

here: $x$ - the age of the person in years; $S$ - sum of the money paid to the insured every year; $S_{m}$ - the marginal capital (capital resources); $r$ - the discount norm $(r=1+i)$.

The analogical possibility that the insured who is $x$ years old will survive until the beginning of the third year (will live two more years after insuring himself) is equal:

$$
{ }_{2} p_{x}=\frac{l_{x+2}}{l_{x}} \text {. }
$$

Therefore the sum to be taken from the customer at this moment is equal:

$$
S_{2}=\frac{{ }_{2} p_{x} \cdot S \cdot S_{m}}{{ }_{2} p_{x} \cdot S+\left(S_{m}-{ }_{2} p_{x} \cdot S\right) \cdot r^{2}} .
$$


We continue such reasoning until $l_{x}$ column in the mortality table ends, ie until the marginal age of the customer $w$ is reached. Having summed up all the received sums, we will receive the calculated bonus $A_{x}$, ie the sum payable by the insured now, so every year, until he is alive, he would receive $S$ Euro of pension [7].

$$
\begin{aligned}
& A_{x}=S_{0}+\frac{1 p_{x} \cdot S \cdot S_{m}}{1 p_{x} \cdot S+\left(S_{m}-{ }_{1} p_{x} \cdot S\right) \cdot r}+ \\
& \frac{2 p_{x} \cdot S \cdot S_{m}}{2 p_{x} \cdot S+\left(S_{m}-{ }_{2} p_{x} \cdot S\right) \cdot r^{2}}+\ldots \\
& \ldots+\frac{{ }_{w-x} p_{x} \cdot S \cdot S_{m}}{{ }_{w-x} p_{x} \cdot S+\left(S_{m}-{ }_{w-x} p_{x} \cdot S\right) \cdot r^{w-x}}
\end{aligned}
$$

or

$$
A_{x}=\sum_{j=0}^{w-x} S_{j}=\sum_{j=0}^{w-x} \frac{{ }_{j} p_{x} \cdot S \cdot S_{m}}{{ }_{j} p_{x} \cdot S+\left(S_{m}-{ }_{j} p_{x} \cdot S\right) \cdot r^{j}} .
$$

The same in case of postnumerando:

$$
A_{x}{ }^{\prime}=\sum_{j=1}^{w-x} S_{j}=\sum_{j=1}^{w-x} \frac{{ }_{j} p_{x} \cdot S \cdot S_{m}}{{ }_{j} p_{x} \cdot S+\left(S_{m}-{ }_{j} p_{x} \cdot S\right) \cdot r^{j}},
$$

here: $x$ - the age of the insured at the conclusion of the contract (when paying the contribution); $A_{x}$ - non-recurring bonus paid by the customer, when the insurance is for the pension for life; ${ }_{n} p_{x}$ - the possibility for a person of $x$ years to live more $n$ years (to live from $x$ until $x+n$ years); $w$ - the marginal age of the customer evaluated by calculations; $S$ - sum of money payable annually to the insured; $S_{m}$ - capital resources; $r$ - discount norm $(r=1+i)$.

Let's analyse the same case when calculating the nonrecurring bonuses by the logistic insurance annuities. For instance, let's say that a 60 year old person wants to receive the annual rent of 2800 Euro paid prenumerando for life. What amount of a non-recurring net bonus must be paid by him, if the capital resources are equal to 1010 Euro, while the discount norm is $-3,5 \%$ ?

In accordance with the conditions of the problem $x=$ $60 ; S_{m}=10^{10} ; S=2800 ; r=1,035$. Based on the provided data, we can write down the following:

$$
A_{60}=\sum_{j=1}^{40} \frac{{ }_{j} p_{60} \cdot 2800 \cdot 10^{10}}{{ }_{j} p_{60} \cdot 2800+\left(10^{10}-{ }_{j} p_{60} \cdot 2800\right) \cdot 1,035^{j}} .
$$

Here $j$ changes from 1 to 40; therefore, when willing to calculate the unknown quantity $A_{60}$, we have to compose two sequences. First of all, on the basis of Table let's compose the sequence ${ }_{j} p_{60}$, ie a sequence of possibilities for a 60 years old person to survive one, two etc years until the very marginal age. Afterwards, on the basis of the formula that had been written down, let's compose a sequence of discounted sums $S_{j}$, which would be included into the nonrecurring contribution $A_{60}$ of the customer.

Let's put these sequences into the table. We provide a fragment of this table below.

Table of discounted sums and chances

\begin{tabular}{|c|c|c|c|c|}
\hline$x$ & $l_{x}$ & $j$ & ${ }_{\imath} p_{x}$ & $S_{x}$ \\
\hline 60 & 66724 & 0 & 1 & 2800 \\
\hline 61 & 64742 & 1 & 0,970296 & 2624,954 \\
\hline 62 & 62698 & 2 & 0,939662 & 2456,116 \\
\hline 63 & 60594 & 3 & 0,908129 & 2293,425 \\
\hline$\ldots$ & $\ldots$ & $\ldots$ & $\ldots$ & $\ldots$ \\
\hline 97 & 189 & 37 & 0,002833 & 2,220981 \\
\hline 98 & 85 & 38 & 0,001274 & 0,965076 \\
\hline 99 & 36 & 39 & 0,00054 & 0,394916 \\
\hline 100 & 9 & 40 & 0,000135 & 0,09539 \\
\hline & & & Total: & 31944,90 \\
\hline
\end{tabular}

Having summed up the members of $S_{x}$ column, we receive 31 944,90 Euro. We then make a conclusion that a 60 year old person, who is willing to receive an annual rent of 2800 Euro for life, now has to pay 31 944,90 Euro.

In both cases the received sum of 31944,90 Euro will be a net bonus. This does not include a supplement, necessary for ensuring the activity of the insurance company. Resources, allocated for the maintenance of the activity of the insurance company can be accumulated taking a certain percentage from the net bonus. The gross bonus is also received from the net bonus.

It has been figured out on the grounds of the lifespan function. Calculating the logistic insurance annuities it was considered that the resources of the capital are practically unlimited (as referred in [8]). When resource limit is approached, ie when system saturation increases, more accurate results are obtained. When marginal capital decreases interest rate should be increased.

\section{Conclusions}

Having examined logistics insurance pensions and having solved several examples, we see that the results are the same, as with usual insurance pensions. However, having evaluated limitation of resources norm we see an obvious influence of resources norm on the size of the premium: with the decrease of resources, premium size increases. Thus a conclusion may be made that logistics insurance pensions can be practically applied when capital resources limitation must be taken into consideration.

One-time premium size of revenue (pension) depends on the value of discount rate used in calculations. There- 
fore, when selecting a discount rate, using logistic insurance pensions, it is important to estimate the size of resources norm. If the anticipated resources are limited and the premium remains the same, it is essential to increase the rate of interests. With the increase of the rate of interests paid pension of the assured decreases, and vice versa, when this rate decreases - premium increases.

The amount of the non-recurring bonus of the rent (pension) also essentially depends upon the value of the discount norm, used in the calculations. In the standard insurance calculations the discount norm is small (usually 2$4 \%$ ). Here it is important to take into consideration the fact that as the interest nom increases, the bonus paid by the insured decreases and vice versa, as this norm decreases the bonus increases.

\section{References}

1. GIRDZIJAUSKAS, S. Logistic (marginal) accumulative models. Informacijos mokslai, 2002, t. 23, p. 95-102 (in Lithuanian).
2. GIRDZIJAUSKAS, S. Insurance: quantitative financial analysis. Kaunas: Naujasis lankas, 2002 (in Lithuanian).

3. CAMERON, Don. Financial mathematics based on annuities (interactive). The University of Queensland [Australia], School of Natural \& Rural Systems management, September. Available from Internet: <www.nrsm.uq.edu.au/Staff/ dcameron/ABUS2002\%20for\%202003/Lectures/>, referred on $10 / 01 / 2004$.

4. SHARPE, W. F.; ALEXANDER, G. J.; BAILEY, J. V. Investments. Prentice Hall International, Inc., 1999.

5. GIRDZIJAUSKAS, S. Financial analysis. Vilnius, 2005 (in Lithuanian).

6. BLAND, D. Insurance: principles and practice. The Chartered Insurance Institute, UK, 1993.

7. GIRDZIJAUSKAS, S. Logistic theory of the capital management: deterministic methods: monograph. Vilnius: Vilnius University Publishing House, 2006, p. 160-195 (in Lithuanian).

8. GIRDZIJAUSKAS, S.; BOGUSLAUSKAS, V. The possibilities for the application of the logistic model of accumulative. Inžinerine ekonomika, 2005, 1(41), p. 7-15.

\section{MODERNUS DRAUDIMO TARIFU SKAIČIAVIMO METODAS - NAUJOVE் DRAUDIMO RINKOJE}

\section{S. Girdzijauskas, J. Čepinskis, E. Jurkonytė}

\section{Santrauka}

Draudimo tarifu skaičiavimas gali būti paremtas nauju - logistiniu (ribiniu) kapitalo vystymosi modeliu. Tyrimais ịrodyta, kad naujai sukurtoji logistinè vystymosi teorija gali būti pritaikyta ne tik palūkanoms apskaičiuoti ar investiciniams projektams vertinti, bet ir diskontuoti vertinėms išraiškoms, dabartinėms pinigų vertėms nustatyti, pinigų srautams valdyti, o tai reiškia, kad ji gali būti taikoma ir draudimo anuitetams skaičiuoti. Straipsnyje konkrečiais pavyzdžiais parodoma, kad galima naujo principo aktuariniu skaičiavimu sistema, paremta logistiniu diskontavimu. Nors skaičiavimai yra sudètingesni ir visiškai ஹ̨manomi tik naudojant informacines technologijas, rezultatai, gauti remiantis logistine teorija, dažniausia yra tikslesni ir patikimesni. Dar daugiau, logistinès teorijos taikymas duoda kokybiškai naujų rezultatų. Pagrindinis šio straipsnio tikslas - pristatyti naujausią draudimo tarifų skaičiavimo metodą ir palyginti paprastujų bei logistinių anuitetinių draudimo tarifų skaičiavimo metodus. Straipsnio uždaviniai: a) aptarti tam tikro amžiaus sulaukimo draudimo ypatumus; b) išnagrinèti ir palyginti paprastujų ir logistinių anuitetinių draudimo tarifų skaičiavimus.

Reikšminiai žodžiai: draudimo rinka, draudimo tarifai, paprastieji ir logistiniai anuitetai, logistinis kapitalas, kapitalo ištekliai.

Stasys GIRDZIJAUSKAS. Dr, Assoc Prof. Dean of Kaunas Faculty of Humanities, Vilnius University (Lithuania) since 2003. Pioneering a new logistic theory in capital management (2006), with the intention of creating his school of scientific thought. His books were generously sponsored by Lithuanian Ministry of Education and Science and Lithuanian State Fund for Science and Studies. Fields of scientific interests: insurance market, financial management, logistic annuities, logistic capital, mathematical modelling.

Jonas ČEPINSKIS. Dr Habil, Professor. Dept of Finance, Faculty of Economics and Management, Vytautas Magnus University (Lithuania). The author of numerous scientific articles and books on environmental issues, financial analysis and sustainable economic development; these are the fields where his scientific interests lie upon.

Edita JURKONYTE். Specialist of Controller's Office, Kaunas City Municipality (Lithuania). Entered PhD studies at Kaunas Faculty of Humanities, Vilnius University (Lithuania) in July 2007 to follow and develop the new logistic theory in capital management by Dr S. Girdzijauskas. 